\title{
MICROCREDIT AS A STRATEGY FOR POVERTY REDUCTION IN NIGERIA: A SYSTEMATIC REVIEW OF LITERATURE
}

\section{OLADAYO NATHANIEL AWOJOBI}

(Received 12 November 2018; Revision Accepted 2 December 2018)

\begin{abstract}
Microfinance was introduced in Nigeria in 2005 to give microcredit to the poor, especially the petty traders. This was to allow them to expand their businesses, increase sales and earn income. This study systematically assessed the impact of the microcredit in poverty reduction. A systematic search for quasi-experimental, observation and comparative studies published between 2008 and 2018 was conducted in five literature databases, lists of relevant studies and websites. Both qualitative and quantitative studies were included in the review and their quality assessed. Inclusion criteria were met by twenty studies. These studies showed how microcredit influence poverty reduction among petty traders who are beneficiaries of microcredit. Among these studies, fourteen focused on microfinance and poverty reduction and seven dealt with microcredit and poverty alleviation. Most studies were quantitative, eight had mixed methods and one had a qualitative analysis. Among the included studies, nineteen supported the hypothesis that microcredit contributes to poverty reduction and only one study objected to this hypothesis. While the findings of this review have revealed that microcredit is a strategy for poverty reduction, there are some challenges that hinder the accessibility to microcredit. This calls for government actions to review its microcredit policy.
\end{abstract}

KEYWORDS: Microcredit, Microfinance, Nigeria, Poverty reduction

\section{INTRODUCTION}

Poverty is real in Nigeria and new data from the Brookings Institute revealed that Nigeria is now the world capital of people living in extreme poverty. According to the findings, Nigeria has bypassed India as the country with people living in extreme poverty in 2018 (Kharas, Hamel, and Hofer, 2018). The trajectories from the Brookings Institute suggest that 87 million Nigerians live in extreme poverty compared to India with 73 million (Kharas, et al., 2018). While extreme poverty is on the rise in Nigeria by six people every minute, in India poverty continues to decrease (Kharas, et al., 2018).

The present democratic dispensation avails successful governments to initiate different poverty reduction strategies to checkmate the rising poverty in Nigeria. One of this anti-poverty reduction strategies is microcredit that is given to petty traders to support entrepreneurship and reduce poverty. Microcredit from microfinance institutions has proven to be a powerful tool for fighting poverty (Appah, John, and Soreh, 2012).

Many current empirical studies have analysed the correlation between microcredit and poverty reduction (Miled and Rejeb, 2015). The outcomes of these studies have shown that microcredit is a strategy for poverty reduction (Appah, et al., 2012; Jegede, Akinlabi, and James, 2011;

Lawanson, 2016). The evidence attached to microcredits in reducing poverty prompted the Nigerian government to introduce microfinance institutions in 2005 (Awojobi, 2014). This is to allow many of the poor informal workers to have access to microcredit to fortify their business,

Oladayo Nathaniel Awojobi, Department of Social Security Bonn-Rhein-Sieg University of Applied Sciences Sankt Augustin, Germany.

(C) 2019 Bachudo Science Co. Ltd. This work is licensed under Creative Commons Attribution 4.0 International license. 
increase income and reduce poverty.

While there has been a scholarly debate on the impact of microcredit on reducing poverty. This study employs a systematic review to assess the impact of microcredit on reducing poverty in Nigeria. Many studies have accessed the impact of microcredit on poverty reduction in Nigeria. However, an electronic search of a systematic review of the impact of microcredit on poverty reduction in Nigeria did not bring any positive result. Therefore, this study is not aware of previous systematic reviews that focus on microcredit and poverty reduction in Nigeria. It is against this background that this study employs a systematic review approach. In doing so, this study presents a research question: What is the impact of microcredit on the poor? The rest of the study is organised as follows. The next section presents the methods employed to answer the research question. The major results are examined in section three while section four is the discussion of the results. The final section deals with the conclusion.

\section{METHODOLOGY}

\section{Systematic reviews}

A systematic review "is a summary and assessment of the state of knowledge on a given topic or research question, structured to rigorously summarise existing understanding" (Ford, Berrang-Ford, and Paterson, 2011, P. 328) There are different techniques of conducting a systematic review, but four common requirements are known across reviews (Lawson, 2012). These are:

- Definition of the problem, inclusion and exclusion criteria;

- $\quad$ The search strategy;

- $\quad$ Criteria for the evaluation of studies; and

- $\quad$ Data extraction (Lawson, 2012:16).

An excellent systematic review might accomplish all the following:

- Establish to what extent existing research has progressed towards clarifying a problem;

- Identify relations, contradictions, gaps, and inconsistencies in the literature, and explore reasons for these (e.g. by proposing a new conceptualisation or theory which accounts for the inconsistency);

- Formulate general statements or an overarching conceptualisation;

- Comment on, evaluate, extend, or develop theory;
- In doing these things, provide implications for practice and policy;

- Describe directions for future research (Siddaway, 2014:1).

While most systematic reviews are conducted with peer reviewed research articles, unpublished papers and grey literature. This study only concentrated on empirical research articles from peer-reviewed journals and it uses the blending of quantitative and qualitative evidence via systematic review to analyse the impact of microcredit on poverty reduction in Nigeria.

\section{LITERATURE SEARCH}

The first step taken by this study in the systematic review approach was to conduct a search on the web through Google search engine. The electronic search produced 172,000 results after using key words such as microcredit, microfinance, poverty reduction and poverty alleviation. Additional literature search was conducted on Google scholar as well as reference lists of full text research articles included in the review.

\section{CRITERIA FOR SELECTING THE SAMPLE STUDIES}

Sample studies had to meet various inclusion and exclusion criteria to be accepted for the review. The search was limited to microcredit and poverty reduction. However, research topic in microfinance and poverty reduction also appeared alongside microcredit and poverty reduction. This study had to include microfinance and poverty reduction research articles that met the criteria of the study for the review since both microfinance and microcredit are connected. Microfinance is also called microcredit which is a type of banking service that is provided to the poor who do not have access to loans from conventional financial institutions. Micro Financial Institutions (MFIs) are responsible for giving out loans to the poor whom own financial accounts with them. This made it possible for both peer review studies on microfinance and microcredit to be included in the selection of literature.

The review of research articles only accepted empirical, peer-reviewed articles focusing on microcredit/microfinance and poverty reduction in Nigeria. Publications out of the scope of this study were excluded. This study aimed to test a hypothesis: microcredit contributes to poverty reduction. 


\section{DATA EXTRACTION}

Data extraction form was used to extract important information. These include study design, geographical location, types of study, date of publication, types of analysis performed and findings. The impact of selected studies was graded in two categories: positive correlation and negative correlation.

\section{RESULTS}

\section{SEARCH RESULTS}

After using electronic search, studies were screened based on title, abstract and full-text screening. A total of 20 research articles met the criteria of the systematic review, 14 focused on microfinance and poverty reduction and the other
7 concentrated on microcredit and poverty reduction. This study describes the characteristics of the selected studies and presents the impact with reference to three categories: economic outcome, social outcome and women's empowerment. The economic outcome was sub-divided into consumption/asset creation; poverty; business; savings, employment, income and sustainable development/well-being. While the social outcome was sub-divided into three areas, these are education; health and social capital. Some studies fall under one category and multiple categories. See Table 1 for summary results from the selected studies.

Table 1: Summary results from selected studies

\begin{tabular}{|c|c|c|c|c|c|c|c|c|c|c|c|}
\hline \multirow[b]{2}{*}{ Study } & \multicolumn{7}{|c|}{ Economic outcomes } & \multicolumn{3}{|c|}{$\begin{array}{l}\text { Social } \\
\text { outcomes }\end{array}$} & \multirow{2}{*}{$\begin{array}{l}\mathrm{W} \\
\mathrm{O}_{1} \\
1 \\
\mathrm{~W} \\
\mathrm{O}_{1} \\
1\end{array}$} \\
\hline & $\begin{array}{l}\mathrm{C} \\
/ \\
\mathrm{A} \\
1\end{array}$ & \begin{tabular}{l|}
$\mathrm{P}$ \\
2
\end{tabular} & $\begin{array}{l}\mathrm{B} \\
3\end{array}$ & \begin{tabular}{l|} 
S \\
4
\end{tabular} & \begin{tabular}{l|}
$E$ \\
5
\end{tabular} & $\begin{array}{l} \\
6\end{array}$ & $\begin{array}{l}\mathrm{S} / \mathrm{W} \\
7\end{array}$ & $\begin{array}{l}\mathrm{E} \\
\mathrm{D}_{8}\end{array}$ & \begin{tabular}{l|}
$\mathrm{H}$ \\
9
\end{tabular} & $\mathrm{SC}_{10}$ & \\
\hline Appah et al. (2012) & & $\sqrt{1}$ & & & & & & & & & $\sqrt{ }$ \\
\hline Jegede et al. (2011) & & $\sqrt{ }$ & & & & & $\sqrt{ }$ & & & & \\
\hline $\begin{array}{l}\text { Obisesan\&Oyedele } \\
(2015)\end{array}$ & & $\sqrt{ }$ & & & & & $\sqrt{ }$ & & & & \\
\hline $\begin{array}{l}\text { Omitoyin\&Sanda } \\
\text { (2013) }\end{array}$ & & & & & & & & $\sqrt{ }$ & & & \\
\hline $\begin{array}{l}\text { Ugochukwu \&Onochie } \\
(2017\end{array}$ & & $\sqrt{ }$ & & & & & & & & & \\
\hline Yahaya et al. (2011) & & $\sqrt{1}$ & $x$ & & $\sqrt{1}$ & & & & & & $\sqrt{ }$ \\
\hline Ihugba et al. (2013) & & $\sqrt{ }$ & & $\mathrm{x}$ & & $\sqrt{ }$ & & & & & \\
\hline Akosile\& Ajayi (2014) & & $\sqrt{1}$ & $\sqrt{ }$ & & & $\sqrt{ }$ & & & & & \\
\hline Ikpefan et al. (2016) & & & $\sqrt{ }$ & & & & & & & & \\
\hline Aideyan (2009) & $\sqrt{ }$ & 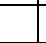 & & $\sqrt{ }$ & & $\sqrt{ }$ & & $\sqrt{ }$ & $\sqrt{ }$ & & \\
\hline Lawanson (2016) & & $\sqrt{1}$ & $\sqrt{ }$ & & & & & & & & \\
\hline Kasali et al. (2015) & & $\sqrt{ }$ & & & & & & $\sqrt{ }$ & & & \\
\hline Emefesi\& Yusuf (2014) & $\sqrt{ }$ & $\sqrt{ }$ & & & & & & & & & \\
\hline Christensson (2017) & & $\sqrt{ }$ & & & & & & & & & \\
\hline $\begin{array}{l}\text { llavbarhe\&lzekor } \\
(2015)\end{array}$ & & & & $\sqrt{ }$ & & $\sqrt{ }$ & & & & & $\sqrt{ }$ \\
\hline $\begin{array}{l}\text { Agbaeze\&Onwuka } \\
(2004)\end{array}$ & & $\sqrt{1}$ & & & & & & & & & \\
\hline Irobi (2008) & & $\sqrt{1}$ & $\sqrt{ }$ & & & & $\sqrt{ }$ & & & $\sqrt{ }$ & \\
\hline $\begin{array}{l}\text { Jolaoso\&Asirvatham } \\
(2018)\end{array}$ & $\sqrt{ }$ & & & & & $\sqrt{ }$ & & & & & \\
\hline Okafor et al. (2016) & & $\mathrm{x}$ & & & & & & & & & \\
\hline Owolabi (2015) & $\sqrt{ }$ & $\sqrt{1}$ & & & & & & $\sqrt{ }$ & & & $\sqrt{ }$ \\
\hline
\end{tabular}

Positive correlation; $x$ Negative correlation 
Note:

$\mathrm{C} / \mathrm{A}_{1}=$ Consumption $/$ Asset creation

$\mathrm{P}_{2}=$ Poverty

$\mathrm{B}_{3}=$ Business

$\mathrm{S}_{4}=$ Savings

$\mathrm{E}_{5}=$ Employment

$\mathrm{I}_{6}=$ Income

$\mathrm{S} / \mathrm{W}_{7}=$ Sustainable development $/$ Wellbeing

$\mathrm{ED}_{8}=$ Education

$\mathrm{H}_{9}=$ Health

$\mathrm{SC}_{10}=$ Social capital

$\mathrm{WO}_{11}=$ Women's empowerment

\section{STUDY CHARACTERISTICS}

To ensure the study's accuracy, a table was created to record the characteristics of each reviewed study - study, methods used, thematic focus and sample size. Of the 20 selected studies, 11 were quantitative studies, 8 mixed methods and one a qualitative. In terms of thematic focus, fourteen of the studies concentrated on microfinance and poverty reduction while the remaining six studies deal

with microcredit and poverty reduction/alleviation. The selected studies' participants consist of entrepreneurs, rural dwellers, fish farmers and cooperative societies. Others are women's groups, household members, officials of MFIs, non-loan beneficiaries and MFIs clients. Seventeen of the studies are impact evaluations/assessments while the remaining three are case studies. Table 2 provides summary characteristics of the selected studies. 


\begin{tabular}{|c|c|c|c|c|}
\hline Study & Method & Thematic focus & Sample size & Type of study \\
\hline Appah et al. (2012) & Quantitative & Microfinance and Poverty reduction & 400 entrepreneurs & Impact assessment \\
\hline Jegede et al. (2011) & Quantitative & Microfinance on poverty alleviation & 80 rural dwellers & Impact evaluation \\
\hline Obisesan\&Oyedele (2015) & Quantitative & Microfinance and poverty reduction & 140 MFIs customers & Impact assessment \\
\hline Omitoyin\&Sanda (2013) & Quantitative & Microcredit and poverty reduction & 135 fish farmers & Impact assessment \\
\hline Ugochukwu \&Onochie (2017) & Quantitative & Microcredit on poverty reduction & MFIs clients & Impact assessment \\
\hline Yahaya et al. (2011 & Mixed methods & Microfinance banks \& poverty alleviation & $\begin{array}{l}400 \text { MFIs customers } \\
80 \mathrm{MFIs}\end{array}$ & Impact evaluation \\
\hline Ihugba et al. (2013) & Mixed methods & Microfinance bank \& poverty reduction & $\begin{array}{l}80 \mathrm{MFIs} \text { customers } \\
40 \mathrm{MFIs}\end{array}$ & Impact evaluation \\
\hline Akosile\& Ajayi (2014) & Mixed methods & Microfinance bank \& poverty reduction & $\begin{array}{l}5 \text { MFIs } \\
3 \text { cooperative societies } \\
40 \text { MFIs customers } \\
20 \text { cooperative societies } \\
18 \text { workers of credit facilities }\end{array}$ & Impact assessment \\
\hline Ikpefan et al. (2016) & Mixed methods & Microfinance and poverty alleviation & $321 \mathrm{MFIs}$ customers & Empirical investigation \\
\hline Aideyan (2009) & Quantitative & Microfinance and poverty reduction & 99 households & Evaluation \\
\hline Lawanson (2016) & Mixed methods & Microfinance and poverty reduction & Small-scale enterprises & Empirical analysis \\
\hline Kasali et al. (2015) & Quantitative & Microfinance and poverty alleviation & $\begin{array}{l}594 \text { loan beneficiaries } \\
540 \text { non-loan beneficiaries }\end{array}$ & Empirical investigation \\
\hline Emefesi\& Yusuf (2014) & Quantitative & Microcredit and poverty alleviation & 95 MFIs customers & Impact assessment \\
\hline Christensson (2017) & Quantitative & Microfinance and poverty reduction & Households & Impact assessment \\
\hline Ilavbarhe\&Izekor (2015) & Quantitative & $\begin{array}{l}\text { Microcredit, women empowerment, } \\
\text { poverty alleviation }\end{array}$ & 100 women microcredit clients & Impact evaluation \\
\hline Agbaeze\&Onwuka (2004) & Mixed methods & Microcredit and poverty alleviation & $\begin{array}{l}105 \text { households } \\
\text { Stakeholders }\end{array}$ & Case study \\
\hline Irobi (2008) & Qualitative & Microfinance and poverty alleviation & Women association & Case study \\
\hline Jolaoso\&Asirvatham (2018) & Quantitative & $\begin{array}{l}\text { Microfinance, poverty and household } \\
\text { income }\end{array}$ & 500 Households & Impact assessment \\
\hline Okafor et al. (2016) & Quantitative & Microcredit and poverty reduction & MFIs clients & Impact evaluation \\
\hline Owolabi (2015) & Mixed methods & Microfinance and poverty reduction & $\begin{array}{l}\text { MFIs \& officials } \\
\text { MFIs clients }\end{array}$ & Case study \\
\hline
\end{tabular}


RESULTS: EVIDENCE OF OUTCOME AND IMPACT

\section{ECONOMIC OUTCOMES}

One of the major objectives of microcredit is to impact the poor economically vis-a-vis poverty reduction. The accessibility of loans by the poor support them to engage in profitable economic activities which can boost their income. Nineteen studies have found microcredit/microfinance positively impacting their beneficiaries economically. Among these studies, four found an improvement in consumption/asset creation (Aideyan, 2009; Emefesi and Yusuf, 2014; Jolaoso and Asirvatham, 2018; Owolabi, 2015). In Kirfi Local Government Area of Bauchi State, microcredit was responsible for the purchased of improved seeds and farm implements (Emefesi and Yusuf, 2014). In a comparative study of two microfinance institutions, Aideyan (2009) found that households receiving microloans increase food consumption more than the households not receiving microloans. However, the study did not find any increase in food consumption of programme households as against the comparison household in the second microfinance institution (Aideyan, 2009).

The primary aim of introducing microfinance institutions in Nigeria in 2005 was to give credit facility to the poor vis-a-vis poverty reduction. Around fourteen studies reported that microcredit/microfinance positively impact poverty reduction among the beneficiaries of microcredit (Agbaeze and Onwuka, 2004; Akosile and Ajayi, 2014; Appah, et al., 2012; Christensson, 2017; Emefesi and Yusuf, 2014; Ilhugba, Bankong, and Ebomuche, 2013; Irobi, 2008; Jegede, et al., 2011; Kasali, et al., 2015; Lawson, 2012; Obisesan and Oyedele, 2015; Owolabi, 2015; Ugochukwu and Onochie, 2017; Yahaya, Osemene, and Abdulraheem, 2011). In Bayelsa State, there was a significant relationship between microfinance and poverty reduction (Appah, et al., 2012). A qualitative study by Irobi, (2008) reveals that microcredit led to poverty reduction among different households and benefit the community. In a similar manner, in Enugu East LGA, microcredit has a positive impact, but not a significant impact on poverty reduction in the study area (Agbaeze and Onwuka, 2004). Only one study found a negative correlation between microcredit and poverty reduction but found a positive impact between the size of MFIs and poverty reduction (Okafor, Ezeaku, and Ugwuegbe, 2016). This outcome was rejected by the study of Christensson (2017) which stated that the existence of many MFIs to do not lead to poverty reduction but the accessibility to MFls is what lead to poverty reduction.

Microcredit allows poor beneficiaries to expand their businesses in order for them to earn a regular income from their investment. Six studies clearly revealed that microcredit/microfinance has resulted in the improvement of the businesses of MFIs clients (Akosile and Ajayi, 2014; Ikpefan, Taiwo, and Isibor, 2016; Irobi, 2008; Jolaoso and Asirvatham, 2018; Lawanson, 2016; Owolabi, 2015). In Mbieri, Imo State, some member of women cooperative society who took microloan invested wisely with their loans in their different businesses which yielded positive results in the long run (Irobi, 2008). In Edo, Osun and Oyo States, the financial services from MFIs and Cooperative Investment and Credit Societies led to the expansion of the businesses of informal workers (Akosile and Ajayi, 2014). On the contrary, the work of Yahaya, et al. (2011) rejected the notion that microfinance influences the growth of small-scale businesses.

MFIs offer saving products to their poor clients. This allows them to have some money saved in order to create a safety net for future expenses. The poor clients save money for investment, children school fees and healthcare. Surprisingly, only two studies reported microcredit/microfinance impacting on microsavings (Aideyan, 2009; llavbarhe and Izekor, 2015). In the southern part of Nigeria, the impact evaluation of two MFIs shows that $72 \%$ and $80.6 \%$ of the treatment households of the two MFls have savings accounts as against $36.5 \%$ and $19.4 \%$ of the control households (Aideyan, 2009). In Edo State, the beneficiaries of microcredit savings have increased as compared to the period when they have no access to microcredit (llavbarhe and Izekor, 2015). The situation in Imo State is different as the study by lhugba, et al. (2013) did not find any positive correlation between microfinance and poverty reduction for poor rural dwellers.

Microcredit creates employment for the poor when they use their credit for investment. One study reported microfinance impacting employment generation for MFIs clients (Yahaya et al., 2011). Some critics have argued against microcredit increasing the income of beneficiaries of microcredit. However, five studies agreed that microcredit improves the income of the poor. In Imo State, the access to credit facility from MFIs expanded the income of MFls clients in rural 
areas (Ihugba, et al., 2013). In a comparative study by Aideyan (2009), the outcomes of the study show that the treatment households have higher incomes compared to the control households. It is also reported that microcredit influenced sustainable development and wellbeing among the beneficiaries of microloan (Irobi, 2008; Jegede, et al., 2011; Obisesan and Oyedele, 2015).

\section{SOCIAL OUTCOMES}

Studies have shown that microcredit/microfinance promote social outcomes such as education, health and social capital to the beneficiaries of microcredit. A total of five studies agreed with this hypothesis (Aideyan, 2009; Emefesi and Yusuf, 2014; Irobi, 2008; Omitoyin and Sanda, 2013; Owolabi, 2015). Among these five studies, four studies reported that microcredit/microfinance positively impacted education for children of MFIs clients (Aideyan, 2009; Emefesi and Yusuf, 2014; Omitoyin and Sanda, 2013; Owolabi, 2015). In Osun State, the beneficiaries of microcredit that comprised $19.2 \%$ could pay the school fees of their children (Omitoyin and Sanda, 2013). Using a non-experimental design, Aideyan (2009) found that the beneficiaries of microcredit increased spending on their children's education when compared to the poor without access to microcredit. In Bauchi State, microcredit to farmers resulted in the improvement of the educational status of their children because their children now attend a better school as compared when there was no microcredit (Emefesi and Yusuf, 2014). In some Nigerian States, the access to microcredit significantly contributes to child education and this show that aside investing in a business, child education is influenced by microcredit (Owolabi, 2015).

There is evidence that microcredit leads to healthcare accessibility. The results of a nonexperimental design in rural areas in the southern part of Nigeria showed that households that have access to microcredit can afford better healthcare services than poor households without access to microcredit (Aideyan, 2009). In terms of social capital, the Obazu Progressive Association, which is a non-governmental organisation formed by women in Imo State has been able to function effectively due to the access to microcredit by its member (Irobi, 2008). Loans to members of the association influenced them economically, politically and socially in their community (Irobi, 2008).

\section{WOMEN'S EMPOWERMENT}

Women are seen to be the poorest among the poor. To assist women to overcome poverty, development institutions, national governments and Non-Governmental Organisations (NGOs) are creating programmes that will give women access to microcredit. One of such programmes is microfinance institution which allows women to have access to microcredit which they can use to finance their businesses and earn income. Around five studies confirmed that the access to microcredit by women empowered them (Appah, et al., 2012; Ilavbarhe and Izekor, 2015; Irobi, 2008; Yahaya, et al., 2011). In Bayelsa State, women's status improved due to their accessibility of loans from MFIs (Appah, et al., 2012). One way to empower women is through income, this is because income makes them invest in businesses and earn them profits. An empirical study in Edo State shows that the access to microcredit empowered women economically this was because their income increased as compared when they have no access to microcredit (llavbarhe and Izekor, 2015). In Kwara State, a mixed method approach revealed that gender has a significant impact on microfinance as a strategy for poverty reduction because women made up the highest number of clients to MFIs (Yahaya, et al., 2011). In line with the empirical findings of Irobi (2008), loans from a cooperative society increased the income of the women which led to improved standard of living, social and political empowerment. Further to this, Owolabi (2015) argues that the credit facility to women increased their business assets. However, Kasali, et al. (2015) assert that women find it difficult to get loans because of their sociocultural background in Nigeria.

\section{FACTORS AFFECTING ACCESS TO MICROCREDIT}

A systematic review of the studies suggests that the access to microcredit is hindered by (i) inadequate loan or equity capital to increase loan-able funds (Emefesi and Yusuf, 2014; Ilavbarhe and Izekor, 2015; Irobi, 2008); (ii) high interest rate (Ikpefan et al., 2016; Omitoyin and Sanda, 2013); and (iii) method of loan payment (Jolaoso and Asirvatham, 2018).

\section{STATUS OF HYPOTHESIS}

Based on the systematic review of selected studies, this study hypothesis: microcredit contributes to poverty reduction is summarised in Table 3. 
Table 3: Status of hypothesis

\begin{tabular}{|c|c|c|c|}
\hline Study & Location & Impact of poverty reduction: summary evidence & $\begin{array}{l}\text { Support of the } \\
\text { hypothesis }\end{array}$ \\
\hline Appah et al. (2012) & Bayelsa State & $\begin{array}{l}\text { The hypothesis is accepted that there is a significant } \\
\text { relationship between microfinance and poverty reduction } \\
\text { in Bayelsa State }\end{array}$ & Yes \\
\hline Jegede et al. (2011) & Lagos State & $\begin{array}{l}\text { The hypothesis which declared that there is no } \\
\text { significant impact of MFls on poverty reduction was } \\
\text { rejected. This signifies that there is a substantial impact of } \\
\text { MFIs on poverty reduction }\end{array}$ & Yes \\
\hline Obisesan\&Oyedele (2015) & Ilorin \& Ibadan & $\begin{array}{l}\text { It indicates that the test is Statistically significant, hence } \\
\text { the Null Hypothesis is rejected, and the alternate } \\
\text { hypothesis is accepted. This result affirms that } \\
\text { Microfinancing contributes to poverty reduction in Nigeria }\end{array}$ & Yes \\
\hline Omitoyin \& Sanda (2013) & Osun State & $\begin{array}{l}\text { The microcredit was used for different purposes such as } \\
\text { fish farming family well-being and child education }\end{array}$ & Yes \\
\hline Ugochukwu \& Onochie (2017) & Nigeria & As microcredit increases, poverty level declines & Yes \\
\hline Yahaya et al. (20111) & Kwara State & $\begin{array}{l}\text { This study accepts the alternative hypothesis in assessing } \\
\text { microcredit as a strategy for poverty reduction as } \\
\text { influenced by gender }\end{array}$ & Yes \\
\hline Ihugba et al. (2013) & Imo State & $\begin{array}{l}\text { The predicted coefficient of microcredit has the strongest } \\
\text { probability }(98 \%) \text { of alleviating poverty in rural areas }\end{array}$ & Yes \\
\hline Akosile\& Ajayi (2014) & Edo, Osun, Oyo States & $\begin{array}{l}\text { The services of MFIs have significantly promoted poverty } \\
\text { reduction in terms of income generating capabilities for } \\
\text { informal sector workers }\end{array}$ & Yes \\
\hline Ikpefan et al. (2016) & Lagos \& Ogun States & $\begin{array}{l}\text { Perhaps the strongest input of microfinance is that it } \\
\text { empowers individuals, by giving them hope, self-esteem, } \\
\text { and the economic powers to perform a greater role in their } \\
\text { development }\end{array}$ & Yes \\
\hline Aideyan (2009) & Southern Nigeria & $\begin{array}{l}\text { The simple test results show that programme households } \\
\text { have made some welfare gains in income and net worth } \\
\text { of household assets }\end{array}$ & Yes \\
\hline Lawanson (2016) & Nigeria & These results explain the role of microfinance in poverty & Yes \\
\hline
\end{tabular}


Kasali et al. (2015)

Emefesi\& Yusuf (2014)

Christensson (2017)

llavbarhe \& Izekor (2015)

Agbaeze \& Onwuka (2004)

Irobi (2008)

Jolaoso \& Asirvatham (2018)

Okafor et al. (2016)

Owolabi (2015)
South West Nigeria

Bauchi State

Nigeria

Edo State

Enugu State

Imo State

Osun State

Nigeria

Edo State alleviation in Nigeria and corroborate the findings of Hulme and Paul (1996) which indicated that the use of microfinance to fight poverty

The results of predicts that microfinance is statistically significant and made a reliable contribution to predicting poverty reduction level

From the findings, it is evident that microcredit facilities have a positive impact on rural farmers' poverty alleviation status

The coefficient has a negative value of -1.579 , confirming the hypothesis that access to microfinance institutions has a positive impact on poverty reduction

This means that the income of the respondents after accessing Microcredit was higher than their income before accessing the microcredit

Based on this, the null hypothesis is rejected, and the conclusion is that micro-credit has positive but nonsignificant impact on poverty

Based on the findings, one could purport that there was difference made by this credit on the women's status that also led to poverty alleviation among their different households and community in general

$100 \%$ of the respondents agreed loan has improve their income

As observed from the result, the coefficient of MCRDT is negative and does have a statistically significant impact on $\mathrm{PI}$. We can therefore say that microcredit has negative and significant impact on poverty reduction

We discover that microfinance is a practical mechanism for poverty reduction. At the minimum, the use of microfinance permits some forms of poverty reduction 
Table 3 affirms that out of the twenty sample studies reviewed, fourteen studies validated the hypothesis, one study did not give credence to the hypothesis. In the case of the remaining five studies, they supported that microcredit assists their beneficiaries in various forms since poverty is multidimensional and it is not measured by income alone. Therefore, the study accepted that their findings gave credence to the study's hypothesis.

\section{DISCUSSION}

This systematic review has shown superlative findings in the form of a positive impact of microcredit on poverty reduction and women empowerment. The analysis of the reviewed studies has shown that microcredit can meet the needs of the poor and taking them out of poverty. Though some studies have argued that the impact of microcredit on poverty reduction is not significant.

Microfinance institutions always prefer to give out loans to the poor who have petty businesses. The loans are meant to expand the businesses of the poor in order for them to increase sales and make profits. The profits then act as the household's income which gives the household the opportunity to have access to healthcare, improved child education, asset creation and the expansion of businesses. In the case of women who have access to microcredit, this study has shown that they are empowered with the profit they made from their businesses. Microcredit empowers women economically, socially and politically and it improves their well-being and that of their households as well as the communities they live. This is the theory of change on the access to microcredit and its positive impact. However, some schools of thought have a problem with this theory. First, many poor households do not make use of microfinance services when they are available (Dunford, 2012). Second, many of the beneficiaries of microcredit do not invest part of their microcredit in their small businesses (Dunford, 2012). Third, most of these small businesses in which savings are invested remain too small with little return on investment which is not significant enough to reduce household poverty (Dunford, 2012).

Nevertheless, "people from poor households tap microfinance services to smooth consumption and build assets to protect against risks ahead of time and cope with shocks and economic stress events after they occur-leading to poverty alleviation" (Dunford, 2013). There is much empirical evidence in which poor households invest their microcredit in their small businesses that do in fact expand and earn additional profit to a significant increase in the household' income and consumption.

Despite the positive impact microcredit has on its beneficiaries, there are some challenges that are hindering the access to microcredit by the poor. One common challenge is the issue of highinterest rate. When the interest rate is high, it prevents the poor from accessing microcredit. This is where policymakers should intervene if the objective of microcredit is to reduce poverty and empowering the poor.

\section{CONCLUSION}

This systematic review has shown that microcredit has the potential of reducing poverty to those who have access to microcredit. While most of the studies have supported the hypothesis that microcredit is a tool for poverty reduction, there still some pitfalls that make it difficult for people to access loans from formal financial institutions. This is while the government needs to review the policy of microcredit/microfinance in Nigeria.

While the findings of this review have revealed that microcredit is a strategy for poverty reduction, it is mandatory for a high-quality empirical evaluation to determine the relationship between the access to microcredit and the rising poverty rate in Nigeria.

\section{REFERENCES}

Agbaeze, E. K., and Onwuka, I. O., 2004. Impact of Microcredit on Poverty Alleviation-inNigeria: The Case of-Enugu East-Local Council. International Journal of Business and Management Review, 2(1), 27-51.

Aideyan, O., 2009. Microfinance and Poverty Reduction in Rural Nigeria. Savings and Development, (3), 293-317.

Akosile, A. I., and Ajayi, O. A., 2014. The Impact of Microfinance Institutions on Poverty Reduction in Nigeria. European Journal of Business and Management, 6(35), 17. 
Appah, B., John, S. M., and Soreh, W., 2012. Analysis of Microfianance and Poverty Reduction in Bayelsa State. Kuwait Chapter of Arabian Journal of Business and Management Review, 1(7), 38-52.

Awojobi, O. N., 2014. Mlicrofinance as a Strategy for Poverty Reduction in Nigeria: Empirical Investigation. International Journal of Current Research, 6(9), 89449851.

Christensson, L., 2017. Microfinance Institutions and Poverty Reduction. Jonkoping University.

Dunford, C., 2012. What If We Turn the Microfinance Theory of Change on Its Head? Evidence Project.

Retrieved October 9, 2018, from http://microfinanceandworldhunger.org/2 012/10/what-if-we-turn-the-microfinancetheory-of-change-on-its-head/

Dunford, C., 2013. How Evidence Is Helping Reframe Our Perspective On Microfinance. Retrieved October 9, 2018, from http://www.cgap.org/blog/howevidence-helping-reframe-ourperspective-microfinance

Emefesi, B. O., and Yusuf, B., 2014. Access and impact of micro credit on poverty alleviation among farmers in kirfi local government area of Bauchi State. IOSR Journal of Agriculture and Veterinary Science, $\quad 7(11)$, 30-35. https://doi.org/10.9790/2380-071113035

Ford, J. D., Berrang-Ford, L., and Paterson, J., 2011. A systematic review of observed climate change adaptation in developed nations: A letter. Climatic Change, 106(2), 327-336. https://doi.org/10.1007/s10584-0110045-5

Hulme, D., and Paul, M., 1996. Finance against poverty (Vol. 1). London: Routledge. Retrieved from https://www.researchgate.net/publication/ 293246304_Finance_against_poverty_V olume_1
Ihugba, O. A., Bankong, B., and Ebomuche, N., 2013. The Impact of Nigeria Microfinance Banks on Poverty Reduction: Imo State Experience. Mediterranean Journal of Social Sciences, 4(16), 97-114. https://doi.org/10.5901/mjss.2013.v4n16p 97

Ikpefan, O. A., Taiwo, J. N., and Isibor, A., 2016. Microfinance (Mf) and Poverty Alleviation In Southwest Nigeria: Empirical Evidence. Journal of South African Business Research, 1-19. https://doi.org/DOI: $10.5171 / 2016.137638$

Ilavbarhe, K. O., and Izekor, O. B., 2015. The role of microcredit in women empowerment and poverty alleviation in Edo State, Nigeria. Journal of Agricultural and Crop Research, 3(6), 81-84.

Irobi, N. C., 2008. Microfinance and Poverty Alleviation: A Case of Obazu Progressive Women Association Mbieri, Imo state Nigeria.Sverigeslantbruksuniversitet.

Jegede, C. A., Akinlabi, B. H., and James, S., 2011. Impact of Microfinance on Poverty Alleviation in Nigeria: An Empirical Investigation. European Journal of Humanities and Social Sciences, 2(1), 97-111.

Jolaoso, E., and Asirvatham, J., 2018. Impact of microfinance on poverty and household income in Rural Areas in Nigeria. Presented at the Jacksonville, Florida.

Kasali, T. A., Ahmad, S. A., and Lim, H. E., 2015. The Role of Microfinance in Poverty Alleviation: Empirical Evidence from South-West Nigeria. Asian Social Science, 11(21), 183-192. https://doi.org/10.5539/ass.v11n21p183

Kharas, H., Hamel, K., and Hofer, M., 2018. The start of a new poverty narrative. Retrieved August 19, 2018, from https://www.brookings.edu/blog/futuredevelopment/2018/06/19/the-start-of-anew-poverty-narrative/

Lawanson, O., 2016. Alleviating Poverty through Micro Finance: Nigerias Experience. 
Asian Journal of Economic Modelling, 4(3), 153-161. https://doi.org/10.18488/journal.8/2016.4. 3/8.3.153.161

Lawson, T. M., 2012. Impact of School Feeding Programs on Educational, Nutritional, and Agricultural Development Goals: A Systematic Review of Literature. Michigan State University.

Miled, K. B. H., and Rejeb, J.-E. B., 2015. Microfinance and Poverty Reduction: A Review and Synthesis of Empirical Evidence. Procedia - Social and Behavioural Sciences, 195, 705-712. https://doi.org/10.1016/j. sbspro.2015.06. 339

Obisesan, F. O., and Oyedele, O., 2015. Assessment of Microfinance Institutions as Poverty Reduction Mechanism in Nigeria. Research Journal of Finance and Accounting, 6(2), 18-26.

Okafor, L. G., Ezeaku, H. C., and Ugwuegbe, S., 2016. Microcredit and Poverty Reduction: A Case of Nigeria. International Journal of Multidisciplinary Research and Information, 230-235.

Omitoyin, S. A., and Sanda, O. H., 2013. Sources and Uses of Microcredit in Poverty Alleviation among Fish Farmers in Osun State, Nigeria. Journal of Fisheries and Aquatic Science, 8(1), 154-159. https://doi.org/10.3923/jfas.2013.154.159

Owolabi, O. E., 2015. Microfinance and Poverty Reduction in Nigeria: A Case Study of LAPO Microfinance Bank. University of Leeds.

Siddaway, A., 2014. What is a Systematic Literature Review and How Do I Do One? Retrieved from https://www. semanticscholar.org/paper/ What-Is-a-Systematic-Literature-Reviewand-How-Do-I-

Siddaway/22142c9cb17b4baab118767e $497 c 93806 d 741461$

Ugochukwu, M. N., and Onochie, G., 2017. Impact of Microcredit on Poverty
Reduction in Nigeria. Online Journal of Arts, Management and Social Sciences, 2(2), 149-163.

Yahaya, K. A., Osemene, O. F., and Abdulraheem, A., 2011. Effectiveness of Microfinance Banks in Alleviating Poverty in Kwara State Nigeria. Global Journal of Management and Business Research, 11(4), 13-20. 